\title{
DEVELOPMENT OF A LINEAR PERMANENT MAGNET GENERATOR TOPOLOGY FOR LOW POWER THROUGH FINITE ELEMENTS
}

\author{
J G MORA SANTOS ${ }^{1}$, E RIVAS TRUJILLO ${ }^{2}$ AND H MONTANA QUINTERO ${ }^{3}$
}

'Engineering School, Engineering Electrical student at Universidad Distrital Francisco José de Caldas, Bogotá, Colombia

${ }^{2}$ Engineering School, Tenured Professor at Universidad Distrital Francisco José de Caldas, Bogotá, Colombia

${ }^{3}$ Engineering School, Engineering Doctorate student in Universidad Distrital Francisco José de Caldas, Bogotá, Colombia

\section{ABSTRACT}

One of the main problems of linear generators is that due to the low speed of translation of their moving part, in order to generate large powers the machine must withstand great efforts which leads to very large devices, therefore, through the use of multiple Medium-power devices instead of a low number of high-power devices, a more suitable waveform is achieved for their integration into the network [1]. In this article, two different linear generator topologies are proposed with characteristics obtained from a compilation of scientific literature, the parameters taken into account for the design and their respective modeling are presented through $2 D$ simulations in COMSOL, as a contribution to the research project TOPOLOGIES OF LOW POWER WIND GENERATOR. The results obtained highlight the second of the proposed topologies, being the one with the best behavior under load, a cleaner terminal signal and greater power output in the face of variations in the magnitude of the load.

KEYWORDS: Linear generator, Magnetic flux, Permanent Magnets, Finite elements, Simulation

Received: Nov 18, 2020; Accepted: Dec 09, 2020; Published: Dec 23, 2020; Paper Id.: IJMPERDDEC202051

\section{INTRODUCTION}

The development of high-efficiencygenerationdevices for low-power applications is important, given the versatility they can have and their ability to be coupled to renewable technologies, such as wind turbines or buoys at sea, to power smallloads but fundamental, such as telemetry [2, 3]. A low power linear generator will be more compact, smaller in size and will have a lighter and simpler mechanical system, accompanied by high efficiency and high power density depending on the geometry used [4-7].

A flat lineargenerator (figure 1) has the most basic and simple geometry of this type of machine, it increases the magnetic flux in the coils by optimizing their shape and reducing the distance between them and the permanent magnet. Planar geometry generators commonly use high-grade ferromagnetic cores, as they reduce coreloss and reduceheatgeneration. Optimal geometry design is essential for good efficiency. [6, 8-10]. 


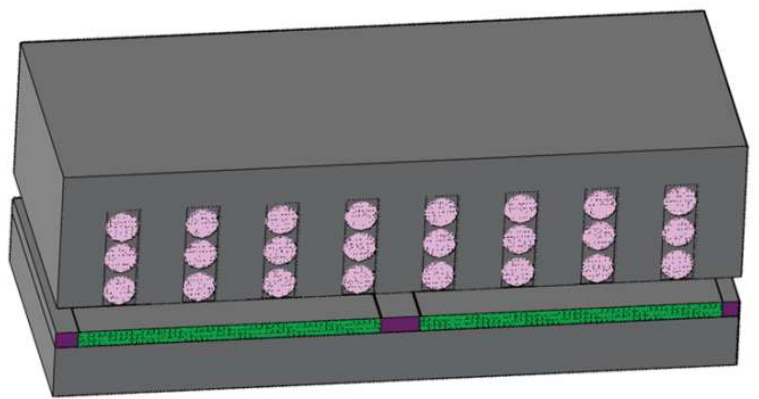

Figure 1: Linear permanent magnet generator flat [Own Elaboration].

Different configurations oflinearpermanent magnetgenerators have been developed so far, a study carried out in [11] performs a classification of the topologies addressed so far, classifying them according to the aspect that is sought to improve in the generator and / or the problem that is being solved, in table 1 the result is observed.

Table 1: Classification of topologies according to their approach [11].

\begin{tabular}{|c|c|c|c|}
\hline Classificati & Subdivision & Aspect that is improved & Aspect to consider \\
\hline $\begin{array}{l}\text { Thought in } \\
\text { geometry }\end{array}$ & $\begin{array}{l}\bullet \\
\text { lat } \\
\bullet \\
\text { ubular } \\
\bullet \\
\text { ultilateral }\end{array}$ & $\begin{array}{lll}\text { Dispersion } & \text { fluxes } & \text { and } \\
\text { efficiency } & & \end{array}$ & $\begin{array}{l}\text { Construction time and } \\
\text { costs }\end{array}$ \\
\hline $\begin{array}{l}\text { Thought in } \\
\text { the location } \\
\text { of magnets } \\
\text { and coils }\end{array}$ & $\begin{array}{l}\bullet \\
\text { oving coil } \\
\bullet \\
\text { oving magnets }\end{array}$ & Response time and efficiency. & $\begin{array}{l}\text { Effective cooling and } \\
\text { moving mass. }\end{array}$ \\
\hline $\begin{array}{l}\text { Thought in } \\
\text { the air gap }\end{array}$ & $\begin{array}{l}\bullet \\
\text { arge magnets } \\
\text { mall magnets }\end{array}$ & $\begin{array}{l}\text { Magnetic flux density in the air } \\
\text { gap }\end{array}$ & $\begin{array}{l}\text { Attraction force } \\
\text { between magnets }\end{array}$ \\
\hline $\begin{array}{l}\text { Thought } \\
\text { about the } \\
\text { cogging } \\
\text { effect }\end{array}$ & $\begin{array}{l}\text { f slotted armor } \\
\text { f armature without slots }\end{array}$ & $\begin{array}{l}\text { Harmonics, braking torque, } \\
\text { efficiency and cogging effect }\end{array}$ & Flux density quantity \\
\hline $\begin{array}{l}\text { Thought in } \\
\text { the Stator- } \\
\text { Traslator } \\
\text { relationship }\end{array}$ & $\begin{array}{l}\bullet \\
\text { hort movable stator } \\
\text { ixed short stator } \\
\text { hort movable translator } \\
\text { ilateral with external traslator } \\
\text { ilateral with internal translator }\end{array}$ & $\begin{array}{l}\text { Active surface of the stator- } \\
\text { traslator interaction and power } \\
\text { density }\end{array}$ & $\begin{array}{l}\text { Construction cost, } \\
\text { Joule losses and End } \\
\text { effect }\end{array}$ \\
\hline $\begin{array}{l}\text { Thought in } \\
\text { the } \\
\text { arrangemen }\end{array}$ & ( & $\begin{array}{l}\text { Efficiency, power and machine } \\
\text { load angle }\end{array}$ & $\begin{array}{lr}\text { Total } & \text { mass of } \\
\text { magnets, } & \text { transients }\end{array}$ \\
\hline
\end{tabular}




\begin{tabular}{|l|l|l|l|}
\hline $\begin{array}{l}\text { Classificati } \\
\text { on }\end{array}$ & Subdivision & Aspect that is improved & Aspect to consider \\
\hline $\begin{array}{l}\text { t of the } \\
\text { magnets }\end{array}$ & $\begin{array}{l}\text { tacked layout } \\
\text { urface disposition }\end{array}$ & $\begin{array}{l}\text { Flux density, harmonic } \\
\text { distortion and power output } \\
\text { adial } \\
\text { xial } \\
\text { Thought in } \\
\text { magnetizati } \\
\text { on patterns }\end{array}$ & $\begin{array}{l}\text { albach } \\
\text { alstance between the } \\
\text { end of each } \\
\text { magnet (leakage } \\
\text { fluxes) }\end{array}$ \\
\hline $\begin{array}{l}\text { Thought in } \\
\text { uasi-Halbach } \\
\text { concatenati } \\
\text { on of the } \\
\text { magnetic } \\
\text { flux }\end{array}$ & $\begin{array}{l}\text { ongitudinal flux } \\
\text { ons flux } \\
\text { ir core }\end{array}$ & $\begin{array}{l}\text { Dispersion fluxes and rated } \\
\text { power per air gap area }\end{array}$ & $\begin{array}{l}\text { Simple construction, } \\
\text { magnitude } \\
\text { synchronous of } \\
\text { reactance, thrust } \\
\text { fluctuations and need } \\
\text { for compensation }\end{array}$ \\
\hline
\end{tabular}

The same topology can bring together several aspects of the different classifications previously exposed, which allows not only to improve a single aspect or to solve a single problem in the machine, it opens a range of possibilities for new designs allowing a certain degree of flexibility when proposing a new topology. When determining the topology to be worked on, it is necessary to bear in mind that what is mainly being sought is a machine with the best possible characteristics and with mechanical forces in the range of those required so as not to compromise the operation of the generator.

For design calculations, electromagnetic theory is used to determine essential aspects, such as the minimum crosssectional area that the conductor must have to withstand the maximum current allowed at an established current density for naturally-cooled generators, and the linear load that the generator supports to avoid overstressing the ferromagnetic material. The other calculations are based on the formulas listed in table 2, in order to estimate the electromotive force generated for a speed of $1 \mathrm{~m} / \mathrm{s}$, a current density equal to $0.6 \mathrm{~T}$, and unit shape and distribution factors.

Table 2: Design formulas [11, 12].

\begin{tabular}{|l|c|l|}
\hline \multicolumn{1}{|c|}{ Variable } & \multicolumn{1}{|c|}{ Formula } & \multicolumn{1}{c|}{ Where } \\
\hline $\begin{array}{l}\text { Minimum cross-sectional area } \\
\text { of conductor }\end{array}$ & $\mathrm{A}_{\mathrm{C}_{\text {_minimum }}}=\frac{\mathrm{I}}{\mathrm{Jc}}$ & $\begin{array}{l}\mathrm{I}=\text { Maximum allowed current } \\
\mathrm{Jc}=\text { Current density }\end{array}$ \\
\hline Number of turns per coil & $\mathrm{N}_{\text {coil }}=\frac{\mathrm{F}_{11} * \mathrm{~h} * \mathrm{~W}}{\mathrm{Ac}}$ & $\begin{array}{l}\mathrm{F}_{\text {ll }}=\text { Filling factor } \\
\mathrm{h}=\text { Groove height } \\
\mathrm{W}=\text { Groove width } \\
\mathrm{Ac}=\text { Cross-sectional area of } \\
\text { selected conductor }\end{array}$ \\
\hline Number of turns per phase & $\mathrm{N}_{\text {phase }}=\mathrm{C}_{\text {phase }} * \mathrm{~N}_{\text {coil }}$ & $\begin{array}{l}\mathrm{N}_{\text {coil }}=\text { Number of turns per coil } \\
\mathrm{C}_{\text {phase }}=\text { Coils per phase } \\
\mathrm{Pu}=\text { useful pole pairs } \\
\mathrm{q}=\text { Slots per pole and phase }\end{array}$ \\
\hline Linear load & $\mathrm{N}_{\text {phase }}=\mathrm{q} * \mathrm{pu} * \mathrm{~N}_{\text {coil }}$ & $\begin{array}{l}\mathrm{N}_{\text {coil }}=\text { Number of turns per coil } \\
\mathrm{I}=\text { maximum allowed current }\end{array}$ \\
\hline
\end{tabular}




\begin{tabular}{|l|c|l|}
\hline \multicolumn{1}{|c|}{ Variable } & \multicolumn{1}{c|}{ Formula } & \multicolumn{1}{c|}{ Where } \\
\hline Conductor length & $\mathrm{L}_{\mathrm{c}}=(2 * \mathrm{~W}+2 * \mathrm{P}) * \mathrm{~N}_{\text {phase }}$ & $\begin{array}{l}\mathrm{W}=\text { groove pitch } \\
\mathrm{P}=\text { Groove width } \\
\mathrm{N}_{\text {phase }}=\text { Number of turns per } \\
\text { phase }\end{array}$ \\
\hline Resistance per phase & $\mathrm{R}_{\text {phase }}=\mathrm{L}_{\mathrm{c}} * \mathrm{R}_{\mathrm{c}}$ & $\begin{array}{l}\mathrm{L}_{\mathrm{c}}=\text { Length of conductor } \\
\mathrm{R}_{\mathrm{c}}=\text { conductor resistance }\end{array}$ \\
\hline & $\mathrm{EMF}=2 * \mathrm{k}_{\mathrm{ff}} * \mathrm{k}_{\mathrm{d}} * \mathrm{~N}_{\text {phase }}$ \\
EMF generated & $\begin{array}{l}\mathrm{k}_{\text {ff }}=\text { Form factor } \\
\mathrm{k}_{\mathrm{d}}=\text { Distribution factor } \\
\mathrm{V}_{\text {maximum }}=\text { Maximum speed } \\
\mathrm{L}_{\text {maximum }}=\text { Stator length } \\
\mathrm{B}=\text { Density of magnetic flux in } \\
\text { the air gap }\end{array}$ \\
\hline Design load resistance & $\mathrm{L}_{\text {stator }} * \mathrm{~B}$ & $\begin{array}{l}\text { EMF = Electromotive force } \\
\text { generated } \\
\mathrm{P}_{\text {design }}=\text { Design Power } \\
\mathrm{R}_{\text {phase }}=\text { Resistance per phase }\end{array}$ \\
\hline
\end{tabular}

\section{PROPOSED TOPOLOGIES}

Emphasizing the space occupied by the linear generator, two bilateral topologies are proposed that allow a better distribution of the generator parts. For the first topology, a bilateral flat iron slotted core generator with moving magnets is proposed, and a concatenation of the magnetic flux longitudinally to obtain a small synchronous reactance. In addition, a stacked arrangement of small magnets is chosen to avoid short circuits and large mechanical stresses, and a Halbach magnetization pattern is used for the longest internal translator.

Since the power generated will be on a small scale, the need to mitigate the cogging effect by reducing the length of the end teeth is not taken into account. Additionally, each external stator will house one coil per phase that is connected in series with the coil of the opposite stator, observing the need for a number of 12 slots as shown in Figure 2.
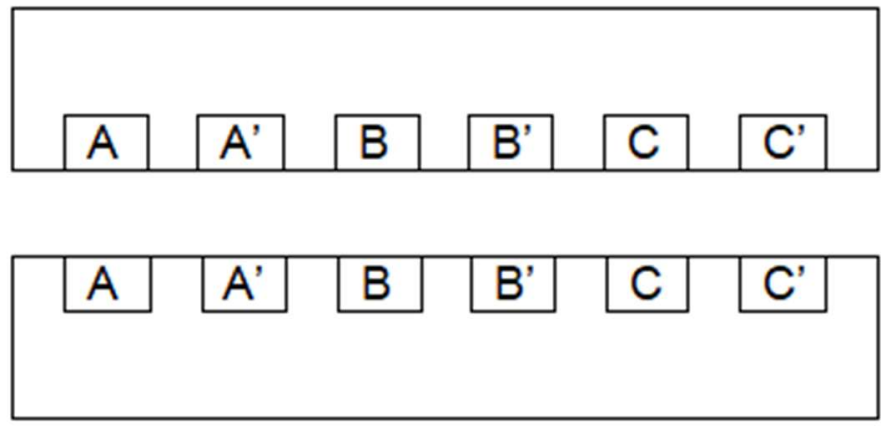

Figure 2: Estator bilateral con devanado de una capa [Ownelaboration].

The expected power is defined at $10 \mathrm{~W}$ per phase and the load resistance is estimated at $716 \mathrm{ohms}$ for a generated emf of $84.66 \mathrm{~V}$ at a speed of $1 \mathrm{~m} / \mathrm{s}$ and an air gap of $5 \mathrm{~mm}$, in figure 3 the resulting structure is observed. 


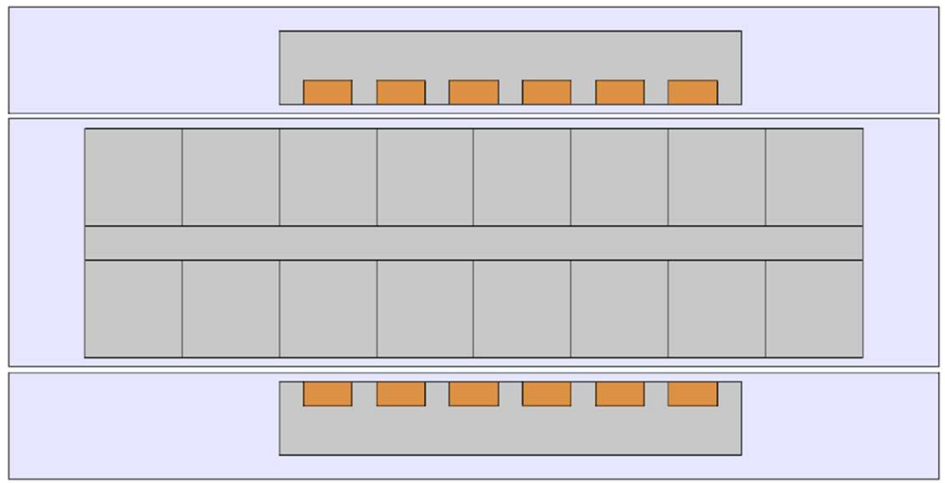

Figure 3: First proposed topology [Own elaboration].

In the same way as in the first topology, the generator will not be designed by shortening the end teeth to reduce the cogging effect, with the difference that an internal stator is chosen that will house two coils per phase connected in series, observing the need for a number of 6 slots for a 3 layer winding as seen in figure 4 .

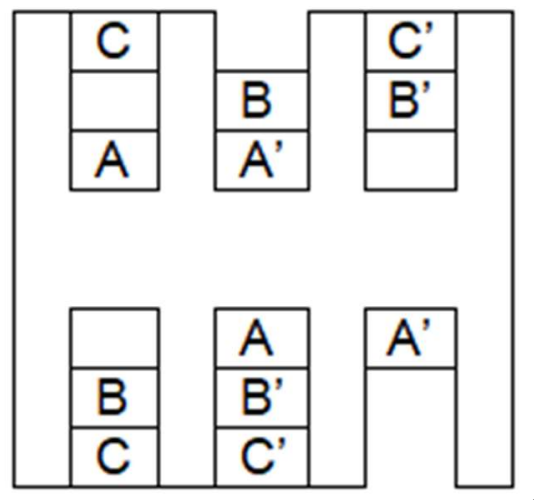

Figure 4: Bilateral stator with three-layer winding and two coils [Own elaboration].

The expected power is defined at $10 \mathrm{~W}$ per phase and the load resistance is estimated at 178 ohms for a generated emf of $42.33 \mathrm{~V}$ per stator at a speed of $1 \mathrm{~m} / \mathrm{s}$ and an air gap of $5 \mathrm{~mm}$, in figure 5 the resulting structure.

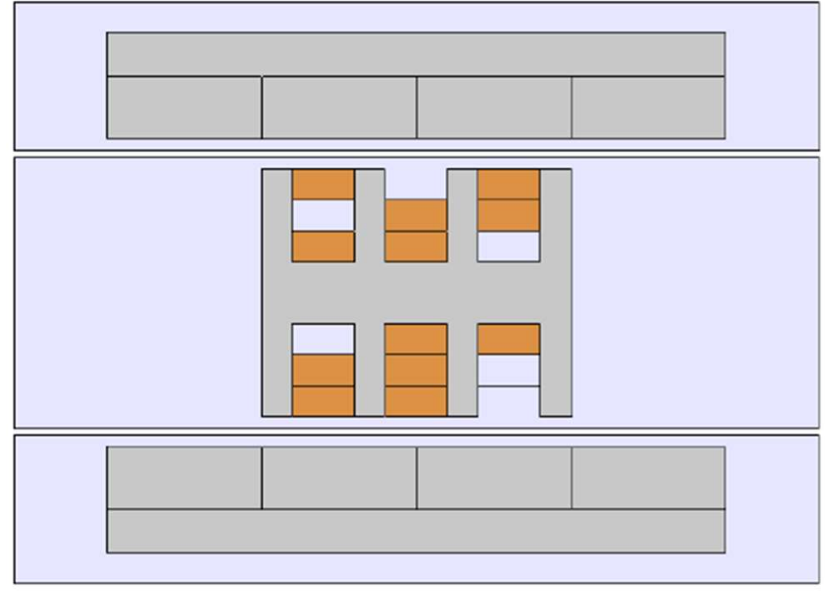

Figure 5: Second topology proposed [Own elaboration].

The dimensions of each topology are shown in Table 3. 
Table 3: Dimensions of the proposed topologies [Own elaboration].

\begin{tabular}{|c|c|c|c|}
\hline Topology & Variable & Quantity & Dimensions \\
\hline \multirow{9}{*}{ First } & Magnets & 16 & $20 \times 20 \times 40 \mathrm{~mm}$ \\
\hline & Total slots & 12 & $10 \times 5 \times 40 \mathrm{~mm}$ \\
\hline & Total teeth & 14 & $5 \times 5 \times 40 \mathrm{~mm}$ \\
\hline & Stators & 2 & $95 \times 15 \times 40 \mathrm{~mm}$ \\
\hline & Traslators & 1 & $160 \times 47 \times 40 \mathrm{~mm}$ \\
\hline & Total turns Winding & 184 & $22 \mathrm{AWG}$ \\
\hline & Load resistance & $716 \Omega$ & ---- \\
\hline & Expected induced voltage & $84.66 \mathrm{~V}$ & ---- \\
\hline & Expected power per phase & $10 \mathrm{~W}$ & ---- \\
\hline \multirow{9}{*}{ Second } & Magnets & 8 & $25 \times 10 \times 40 \mathrm{~mm}$ \\
\hline & Total slots & 6 & $10 \times 15 \times 40 \mathrm{~mm}$ \\
\hline & Total teeth & 8 & $5 \times 15 \times 40 \mathrm{~mm}$ \\
\hline & Stators & 1 & $50 \times 40 \times 40 \mathrm{~mm}$ \\
\hline & Traslators & 2 & $100 \times 17 \times 40 \mathrm{~mm}$ \\
\hline & Total turns Winding & 184 & $22 \mathrm{AWG}$ \\
\hline & Load resistance & $178 \Omega$ & ---- \\
\hline & Expected induced voltage & $42.33 \mathrm{~V}$ & ---- \\
\hline & Expected power per phase & $10 \mathrm{~W}$ & $\begin{array}{ll}--- \\
\end{array}$ \\
\hline
\end{tabular}

\section{MODELING WITH FINITE ELEMENTS IN COMSOL}

Once the design calculations are finished, the resulting topology is modeled in COMSOL, in order to simulate a movement scenario of the moving part of the generator in which the behavior of the output is observed in no-load and under load, the procedure is repeated making variations in the load and the results of the variation of the output power are recorded. Figure 6 and Figure 7 show the magnetic flux distributions in the generators.

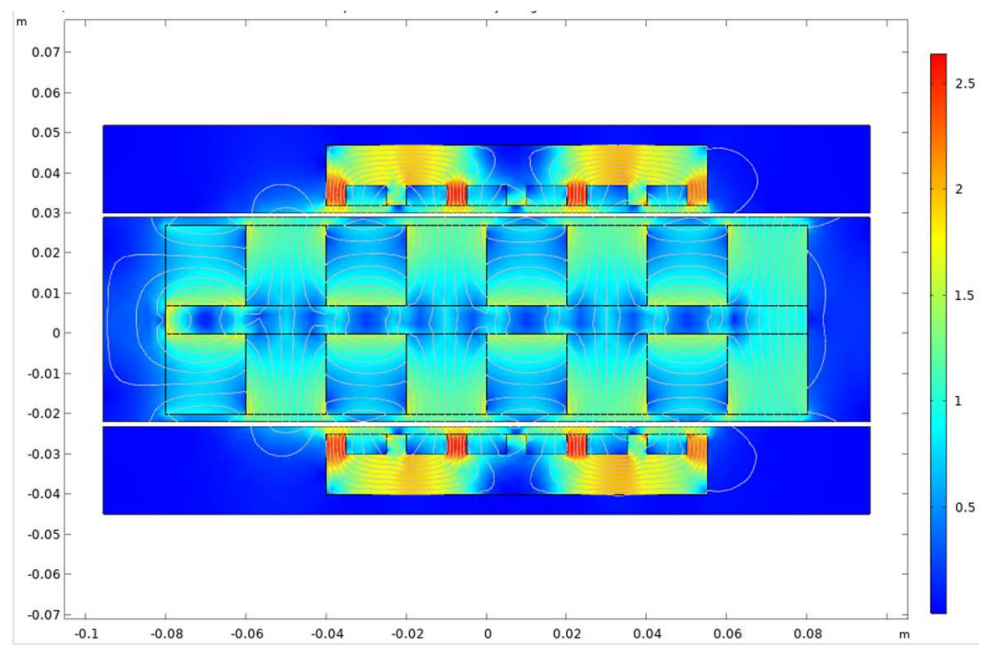

Figure 6: Modeling of first topology [Own elaboration]. 


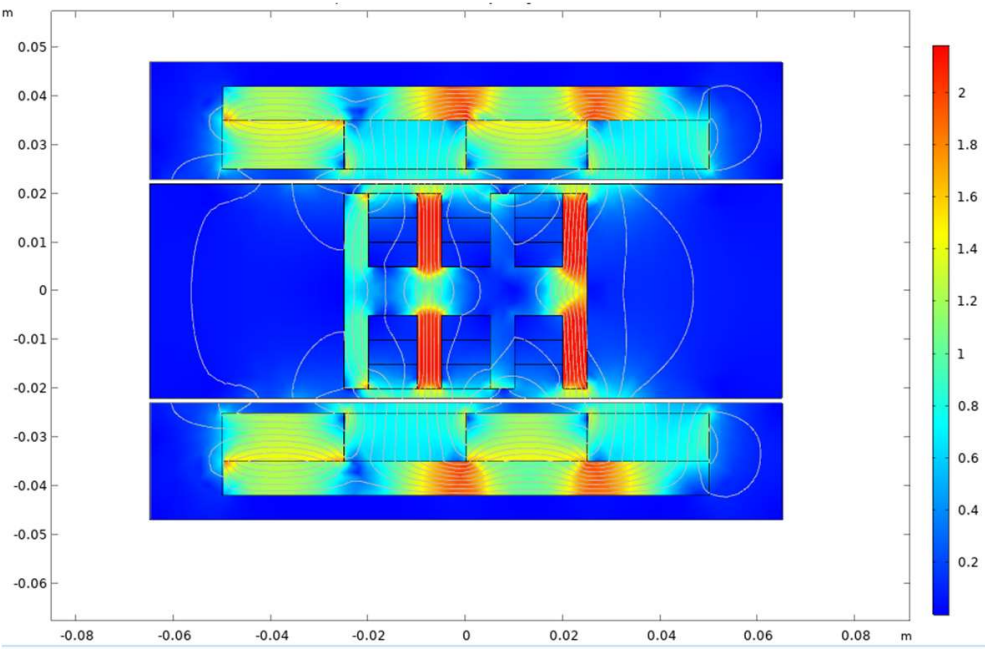

Figure 7: Modeling of second topology [Own elaboration].

Table 4 shows the results of the voltage at the generator terminals for the no-load and under-load scenarios of each of the proposed topologies, the estimated magnitudes of the voltages are plotted as a constant and the simulation times are adapted according to according to the frequency of each generator. It is observed that there is no change in the magnitude of the voltage under load in any of the topologies, however for topology one, phase 2 presents a lower voltage than the estimated one and phase one a greater magnitude than it, somewhat that does not occur in topology two whose phases are not out of phase but have the same magnitude.

Table 4: Results of the modeling with finite elements [Own elaboration]

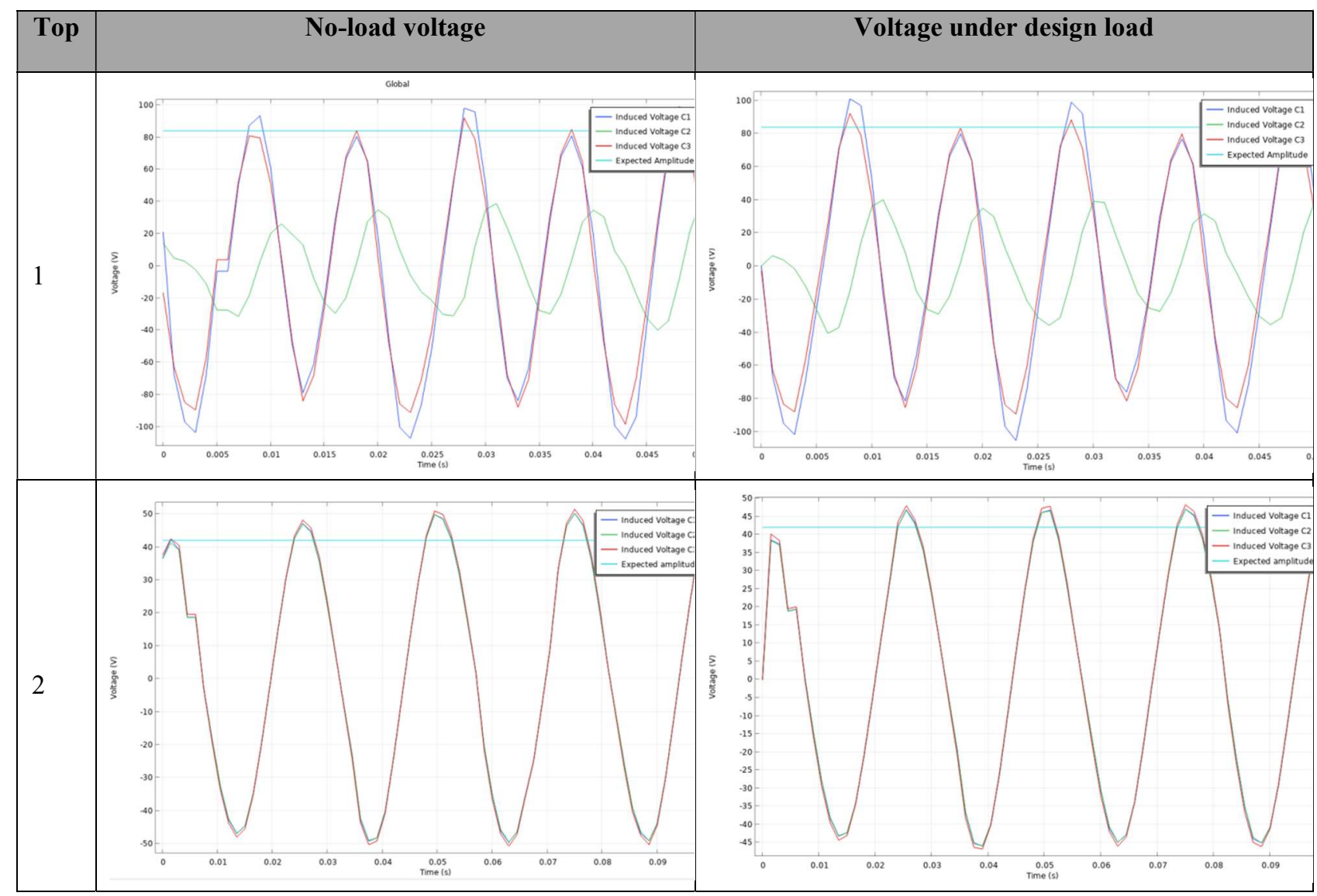


For the variation of the output power to the change in the load, the results are recorded in graph 1 under different magnitudes in the load, in order to determine the topology that presents the best behavior under these conditions. For this, the average power per phase of each simulation is taken into account, observing a higher power output from topology 1 , however, it was observed that the power in this topology is distributed in a greater way in phase one and three. In phase two, in addition to the voltage drop, the power decreases significantly.

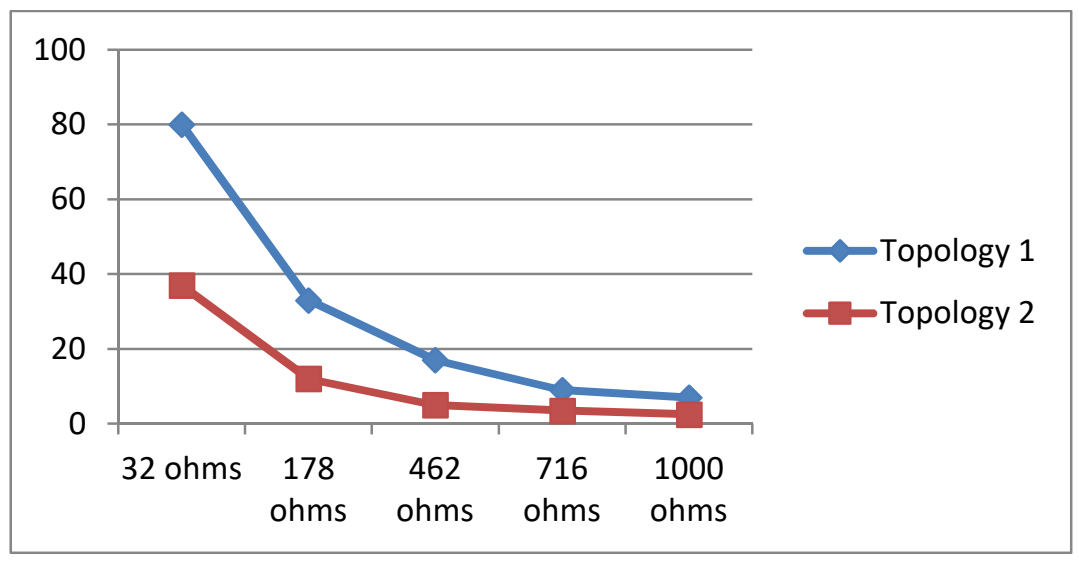

Graph 1: Power variation at different loads [Own elaboration].

\section{CONCLUSIONS}

The topology that showed the best behaviors in a state under load and when empty was topology two, whose behavior was not affected by variations in load, additionally, the space occupied by it is the smaller of the two proposed topologies, which It gives you additional value in a structural way.

The second topology presents certain dispersion flows that must be taken into account if an efficiency analysis of the generator is made, caused by the distance between each translator and the end effect that characterizes this type of generator.

Despite the fact that the second topology presents a voltage drop in phase two, its applicability can be improved by adapting devices or additional elements for signal processing, which, in the same way, allow correcting the signal lags as in the case of the first topology.

\section{REFERENCES}

1. C. García Saiz. (2015). Diseño, Dimensionado y Simulación de un Generador Lineal para el Desarrollo de una Boya de Generación de Energía Undimotriz (Final degree project). Universidad de Cantabria, España.

2. M. Ardestani, N. Arish \& H. Yaghobi. (2019). A New HTS Dual Stator Linear Permanent Magnet Vernier Machine with Halbach Array for Wave Energy Conversion. ELSEVIER, Physyca C: Superconductivity and its Applications, Semman University, Iran

3. I. Abdalla, E. Z. Zainal, N. A. Ramlan, Firmansyah, A. R. A. Aziz \& M. R. Heikal. (2017). Cogging Force Investigation of a Free Piston Permanent Magnet Linear generator. IOP Conferences Series: Materials Science and Engineering, ICMER, Malasysia.

4. Tapia-Hernández, M. Ponce-Silva, N. Mondragón-Escamilla \& L. Hernández-González. (2016). Impacto de la Geometría en 
el Efecto Fin de Generadores Lineales. Información Tecnológica, 27 (4), 133-138, México.

5. P. Asef, R. B. Perpina, M. R. Barzegaran, A. Lapthorn \& D. Mewes. (2017). Load Identification of Different Halbach-Array Topologies on Permanent Magnet Synchronous Generators using the Coupled Field-Circuit FE Methodology. ELSEVIER, Electric Power Systems Research.

6. X. Liu, H. Yu, Z. Shi, T. Xia \& M. Hu. (2017). Electromagnetic-Fluid-Thermal Field Calculation and Analysis of a Permanent Magnet Linear Motor. ELSEVIER, Applied Thermal engineering, Southeast University, China.

7. M. F. M Naafi, T. Ibrahim, N. M. Nor \& M. A. Firdaus bin M. Hamim. (2015). Design and Modelling of a Portable Pico Linear Generator for Wave Energy Conversion System. Applied Mechanics and Materials, 785, 300-304, Malaysia.

8. B. Ganji \& M. H. Askari. (2016). Analysis and Modeling of Different Topologies for Linear Switched Reluctance Motor using Finite Element Method. ELSEVIER, Alexandria Engineering Journal, Alexandria University, Iran.

9. Y. Sun, Z. Xu, Q. Zhang \& L. Liu. (2020). A Plate Moving-Magnet Linear Generator Designed for Free-Piston Engines. IEEE Access, Nanjing University of Science and Technology, 8, China.

10. Musolino, R. Rizzo \& M. Raugi. (2015). A Semi-Analytical Model for the Analysis of a Permanent Tubular Linear Generator. IEEE, 4th International Conference on Renewable Energy Research and Applications, University of Pisa, Italy.

11. J. G. Mora Santos, E. Rivas Trujillo \& H. Motana Quintero. (2020). Comparative Study of a Linear Permanent Magnet Generator of Low-Power through the Finite Elements Method. International Journal of Mechanical and Production Engineering Research and Development, IJMPERD, 10 (3), 16055-16064, Colombia.

12. J. G. Mora Santos, E. Rivas Trujillo \& H. Motana Quintero. (2020). Modeling of a Linear Permanent Magnet Generator for Low Powers using Finite Elements. International Journal of Mechanical and Production Engineering Research and Development, IJMPERD, 10 (3), 14999-15010, Colombia. 

